\title{
Gureba Hastanesi’nde Ölüm ve Ölüme İlişkin Masraflar
}

Death and Expenditures Related to Death in the Gureba Hospital

\section{Kenan Göçer}

\section{$\ddot{O ̈ z}$}

Tanzimat döneminde sivil bir hastane olarak kurulan Gureba Hastanesi, Bezmialem Valide Sultan tarafından kurulduğu yıldan itibaren hizmetlerini arttırmaya devam etmiştir. 1860 ila 1893 yılları arasında hastaların ölümü, ölüm nedeni ve oranları, hastalık ve ölüm tanıları, ölüme ilişkin masraflar ve ölümle doğrudan ilişkili personel maliyetlerine dönük kesit bilgiler verilerek, elverdiğince İstanbul'un sağlığına ilişkin çıkarımlarda bulunulmaya çalışılmıştır.

Anahtar Kelimeler: Bezmialem, Gureba Hastanesi, Hastalık ve Ölüm Tanıları, Ölüm Masrafları, İstanbul.

JEL Sinıflandırma Kodları: N35, N95.

Yrd. Doç. Dr., Sakarya Üniversitesi, Uygulamalı Bilimler Yüksekokulu, Uluslararası Ticaret ve Lojistik Bölümü, kenangocer@ sakarya.edu.tr

Bu makale iThenticate sistemi tarafından taranmıştır.

Makale Gönderim Tarihi: 01.03.2016

DOI: $10.17550 /$ aid. 86744 


\begin{abstract}
The Gureba Hospital, being established by Bezmialem Valide Sultan as a civilian hospital in the Tanzimat period, has continued increasing its services since its foundation. Between 1860 and 1893 have been tried to make inferences with regard to Istanbul's health by informing about to the death of patients, causes and rates of death, disease, death diagnoses, expenditures related to deaths and section details to staffs expenditures directly related to deaths.
\end{abstract}

Keywords: Bezmialem, The Gureba Hospital, Disease, Death Diagnoses, Death Expenditures, Istanbul.

JEL Classification Codes: N35, N95. 


\section{Giriş}

Osmanlı Devleti'nin askerî yenilgiler üzerinden başlayan çöküşü durdurmaya karşı uygulamaya koyduğu politikalardan biri de, hiç kuşkusuz şehirlerin, özellikle de başkent İstanbul'un hıfzıssıhhası/hijyenidir. Çünkü tıp ve sağlık kurumları, XIX. yüzyılı belirleyen pozitivist zihniyet içinde modernleşmenin, bilim ve teknolojinin en önemli sembolleri durumuna gelmişlerdi. ${ }^{1}$

Bu anlamda sağlık çalışmaları, başkentin her tarafında 'görünür' olmaya başlamış, gazete ve dergiler de bu konuyu işlemeye başlamıştı. Bezmialem Valide Sultan'ın yaptırdığı Gureba Hastanesi de, sivil çalışmalara (vakıf) örnek bir sağlık kuruluşu olarak Tanzimat'tan birkaç yıl sonra varlı̆̆ını göstermeye başlamıştır.

Yakın zamana kadar adı daha çok Vakıf Gureba Hastanesi (VGH) veya Vakıf Gureba olarak bilinen Gureba Hastanesi ile ilgili nispeten çok sayıda makalenin yanı sıra birkaç kitap ve tez düzeyinde çalışma yapılmıştır. Bu çalışmalarda, genellikle kurumun idarî tarihi veya tıp-sağlık tarihi bakımından önemi üzerinde durulmuştur. Hastanenin sağlık hizmetleri sunma yönü kadar bir de bu hizmetlerin önemli bir unsuru olarak değerlendirilmesi gereken ekonomik tarafı da vardır: Personel maaşları, hastane cari giderleri, ecza ve demirbaş masrafları vs.

Bu çalışmamızda hastanedeki hastaların hangi hastalıktan ötürü yattığı ve öldügüu, ölüm oranları, ölenlerin hizmetlerinde görevli personel, personelin vazifesi ve maaşı, ölüm masrafları ve masrafların içerikleri üzerinde durulacak, bu çerçevede birtakım mali ve iktisadi verilere yer verilecektir.

\section{Vakıf Gureba Hastanesi'nin Kısa Tarihi}

Kurulduğu yıllarda Gureba Hastanesi, Gurebâ-i Müslimîn Hastanesi ve Yenibahçe'deki Gurebâ-i Müslimîn Hastanesi gibi adlar taşıyan hastanenin bugünkü adı 'Bezmiâlem Vakıf Üniversitesi Tıp Fakültesi

1 Fatih Tetik, “Osmanlı Devleti’nin Tanzimat Dönemi Kamu Sağlı̆̆ı Politikası”, Marmara Üniversitesi Türkiyat Araştırmaları Enstitüsü, Yayınlanmamış Yüksek Lisans Tezi, İstanbul 2007, s.9. 
Hastanesi'dir. Hastanenin kurucusu Bezmiâlem Valide Sultan (?-1853), Sultan II. Mahmut'un (1808-1839) yedi kadın efendisinden ikincisi olup, ${ }^{2}$ Sultan II. Mahmut'un ölümü üzerine şehzade Abdülmecit (18391861) henüz on altı yaşında iken tahta çıkınca, saray teşrifat kuralları gereği Valide Sultan unvanını alarak Nakşidil Valide Sultan'dan boşalan ve yirmi iki yıl boyunca sahipsiz kalan Valide Sultanlık makamına gelmiştir $^{3} \mathrm{Bu}$ tarihten sonra da Bezmiâlem Valide Sultan olarak tanınmıştır. Oğlunun padişahlığı sırasında devletin kendisine tahsis etmiş olduğu maaş ve diğer gelirlerinin önemli kısmını fakirleri doyurmak, ihtiyaçlarını gidermek, rahmet ve şükranla anılmasını sağlayacak pek çok hayır eseri yaptırmak yolunda sarf etmiştir. ${ }^{4} \mathrm{Bu}$ eserlerden birisi de, adını yukarıda andığımız hastanedir.

Hastanenin açılışı, inşaatın tamamlandığı 1261/1845 yılında planlanır $^{5}$ ve Bezmialem'in oğlu Sultan Abdülmecid, hastane yap1mıyla bizzat ilgilenir. Ancak hizmete açılışına yakın bir zamanda duvarlarındaki rutubeti fark eden Abdülmecid, eksikleri tamamlatmadan hastaneyi açtırmaz. Daha sonra 11 Mart 1847 tarihini taşıyan iradesiyle son eksikleri de tamamlatarak ertesi gün, yani 12 Mart 1847 Cuma günü açılışı gerçekleştirilir ${ }^{6}$ Açılış iradesinde hastaneye 13 Mart 1847 Cumartesi günü fakir hasta nakledilmesi emredilmiş, ancak hastaların nereden nakledileceği belirtilmemişti. Bazı kaynaklarda ilk hastaların Süleymaniye Darüşşifası'ndan getirtildiği kayıtlıdır. Süleymaniye Darüşşifası'nın 28 Aralık 1847 tarihinde boş olması bu görüşü kuvvetlendirmektedir. ${ }^{7}$

2 Ahmed Akgündüz, İslam Hukukunda Kölelik-Cariyelik Müessesesi ve Osmanlı'da Harem, Osmanlı Araştırmaları Merkezi Yayınları, İstanbul 2006, s. 347.

3 M. Hüdai Şentürk, "Bezmiâlem Valide Sultan”, İslam Ansiklopedisi, Cilt: 6, Türkiye Diyanet Vakfı Vakıf Yayınları, İstanbul 1992, s. 108; Yılmaz Öztuna, Osmanlı Devleti Tarihi Medeniyet Tarihi, Cilt: 2, Ötüken Yayınları, İstanbul 2006, s. 254.

4 Şentürk, a.g.m., s. 109.

5 Zîver Paşa, Âsâr-1 Zîver: Dîvan ve Münşeât, (nşr. Yusuf Bahaeddin), Matbaa-i Vilayet, Bursa 1313 [1896], s.2-5, 147; BOA. İ. MMS. 25/665; Takvim-i Vekayi, nr. 294, 23 Zilkade 1261 [23 Kasım 1845].

6 BOA. İ. DH. 138/7116, 23 Rebiulevvel 1263 [11 Mart 1847].

7 Nuran Yıldırım, İstanbul'un Sağlık Tarihi, İstanbul 2010 Avrupa Kültür Başkenti Ajansı İstanbul Üniversitesi Projesi No 55-10, İstanbul 2010, s.199. 
201 yatak kapasite ile kurulan hastane,${ }^{8} 1892$ y1lında kapasitesini 300'e çıkarmış ancak aşırı ihtiyaç nedeniyle yer yatakları da kullanılarak hastanede yatan hasta sayısı 350 'ye kadar yükseltilmişti. ${ }^{9}$ Hastaneye bu kadar rağbet edilmesinin nedenini birkaç noktada arayabiliriz. Birincisi, o yıllarda zindanlarda yatan mahkûmların tedavi edileceği bir zaptiye hastanesi bulunmadığından hastalanan mahkûmların bu hastaneye gönderilmesidir. ${ }^{10}$ İkincisi, Hindistan kökenli ölümcül bir salgın hastalık olan koleranın 1822'lerden beri Osmanlı topraklarındaki yayılışıdır. ${ }^{11}$ XIX. yüzyılın başlarından itibaren Avrupa'dan çekilen veba, bu yüzyılın ortalarına kadar Osmanlı üzerindeki etkisini azaltarak yerini, ondan daha öldürücü olan ve daha hılı bir bela olan koleraya bırakmıştır. ${ }^{12} \mathrm{Bu}$ arada 1845-1846 yıllarında İstanbul'daki çiçek salgınını da unutmamak gerek. ${ }^{13}$ Üçüncüsü, Kırım ve Doksanüç Harbi ve savaş sonu göçleridir. Dördüncü ve son neden ise Süleymaniye Bîmarhanesi'nde akıl hastaları dışında kalan hastaların buraya naklidir. ${ }^{14}$

Bahsedilen nedenlerden ötürü yatak kapasitesini neredeyse ikiye katlamak zorunda kalmış ve deyim yerindeyse hastalarla dolup taşmış Vakıf Gureba'nın temel misyonu, hastaları iyileştirip sağlıklarına kavuşma ve hayatlarına kaldıkları yerden devam etme arzularıdır. Ancak vefat edenlerin sayısı, istatistikî verilere dökülecek kadar dikkat çekicidir.

8 Kazım İsmail Gürkan, Bezm-i Âlem Vâlide Sultan Vakıf Gureba Hastanesi Tarihçesi, Özışık Matbaası, İstanbul 1967, s.31.

9 Nuran Yıldırım, Gureba Hastanesi'nden Bezmiâlem Vakıf Üniversitesi'ne, Bezmiâlem Vakıf Üniversitesi Yayını, İstanbul 2013, s.127 ve 130.

10 Yildırım, 2013, s.123.

11 Mesut Ayar, Osmanl Devletinde Kolera İstanbul Örneği (1892-1895), Kitabevi, İstanbul 2007, s.22.

12 Ayar, a.g.e., s.3.; "İstanbul'da ilk kolera salgını 1831 Haziranında başladı. Günlük ölümler 12'den 200'e kadar yükselerek, toplam 6.000'e ulaştı.” Ayar, a.g.e., s.23.

13 Yildırım, 2013, s.121.

14 Fatih Artvinli, Delilik Siyaset ve Toplum: Toptaşı Bimarhanesi (1873-1927), Boğaziçi Üniversitesi Yayınevi, İstanbul 2013, s.39-40. 


\section{Hastane Personeli ve Ölümle İlgili Görevliler}

Hastanelerin temel işlevi, hastayı hastaneye kabul ederek tedavisini gerçekleştirdikten sonra taburcu etmektir. Bu işlevi yerine getirecek olan da hastane personelidir. VGH personelini ${ }^{15}$ genel olarak idarîmalî, sağlık, yardımcı hizmetler ve dinî personel olarak dört başlıkta ele alabiliriz: İdarî-malî personele hastane müdürü, müdür yardımc1s1, kâtib-i evvel, kâtib-i sânî, vekîl-i harc, câbî vb. örnek verilebilir. Sağlık personeli tabîb-i evvel, tabîb-i sânî, tabîb-i sâlis, cerrâh-1 evvel, cerrâh-1 sânî, muâvin-i cerrâh, eczâc1-1 evvel, eczâc1-1 sânî, eczâc1-1 sâlis, hâven-zen, sülükçü vb. personellerden meydana gelmektedir. Hastanenin üçüncü başlıkta ele aldığımız sayıca çok ve fakat çeşit itibariyle sınırlı olan yardımcı hizmet personeline elbise emîni ve yamağı, müvezzi', ser-hademe, hizmetçiler, bevvâbân, aşçı, aşçı yamağı, berber, bekçi, terzi, çamaşırcı, bahçıvan, meydancı vb. örnek olarak verilebilir. Son olarak dinî personel başlığında ele alınacak personel ise muvakkit, gassal ve muâvin-i gassaldir. Bunlara, hastane camisi görevlileri ${ }^{16}$ cuma vâizi, vâiz, hatip, imam-1 evvel, imam-1 sâni, müezzin-i evvel, müezzin-i sâni, kayyım-1 evvel ve kayyım-1 sâni de eklenebilir.

Hastane vakfiyesinde unvanı sayılan söz konusu personellere tahsis edilecek maaş, şartlı ücret ve fodla ${ }^{17}$ bedellerine ayrıntılı bir şekilde yer verilmişken, hastane vakıf defterlerindeki personel giderleri hesaplarında sadece muvakkit, gassal ve gassal yardımcısı zikredilmektedir. Söz konusu görevlilere hastanenin günlük muhasebe kayıtlarında rastlanmadığından dolayı, İstanbul'un başka camilerinin kadrosunda oldukları, hastane camisine belirli gün ve gecelerde görevlendirdiklerini düşündürmektedir. ${ }^{18}$

Hastanenin hizmet verdiği hedef kitlenin, vakfiyesinde de vurgulandığı gibi Müslüman, fakir, garip ve kimsesizlerden oluştuğunu

15 BOA. EV. d. 15428, 1270.Za.19. [6 Ağustos 1854].

16 Bezmiâlem Valide Sultan, Vakfiyeler, 15 Vakfiye, 1256-1269 [1840-1853] Vakfiyeler Genel Müdürlüğü Arşivi: 634 Numaralı Vakfiye Defteri, 83. Sayfa, 13. Sıra, 126. Sayfa, 27. Sıra'dan aktaran Kenan Göçer, "Bezmiâlem Valide Sultan ve Gureba Hastanesi Vakfiyesi”, Çankırı Karatekin Üniversitesi İktisadi ve İdari Bilimler Fakültesi Dergisi, Çankırı 2014, C.4, S.1, ss. 123-150, s.141.

17 Günlük ekmek tayinatı.

18 Göçer, a.g.m. s.140. 
göz önüne alarak, hastaların hastaneye kabulü uygulamasına baktı̆̆1mızda, çok ince detaylara yer verildiği görülmektedir. Örneğin hasta, dilekçesiyle hastane nazırına başvurduğunda, doktorlara havale edilmektedir. Doktorlar, hastanın durumunu muayene ettikten sonra hastaneye kabulünü uygun gördüklerinde bir belge düzenlemekte ve söz konusu belge, hastane nazırlığına yönlendirilerek, nazırlık tarafından tarih ve numara verilmesi sağlanmaktadır. Bunun üzerine hasta, boş bir koğuşa konarak geceyi, üzerindeki elbisesiyle ve doktorların hazırlayacakları ilaçları ve yemeği alarak geçirmektedir. Bir gece boş koğuşta konaklamasının nedeni ise veba ve başka bulaşıcı hastalık olup olmadığııdan emin olunduktan sonra ilgili yerlere konulması gerektiğidir. ${ }^{19}$

Hastanın kendisine ilişkin bu uygulamanın benzeri, elbisesi ve varsa parası için de geçerlidir. Yine aynı belgeden öğrendiğimize göre hasta, hastaneye müracaata geldiğinde elbisesi ve nakit parasını kendi eliyle teslim etmesi, buna gücü yetmiyorsa gözü önünde hastane müdürü, başhekim ve hastane imamının da hazır bulunduğu bir ortamda torbaya konulması sağlanarak, torbanın ağzı iple bağlanıp mühürlenmektedir. Hasta eğer iyileşirse başhekim, durumu bir belge ile hastane nazırlığına bildirir ve çıkış işlemlerine ilişkin gerekli kayıtlar yapıldıktan sonra hastanın elbise ve nakit paralarının bulunduğu torbas1, hastanın huzurunda ve mühürler kontrol edildikten sonra açılarak iade işlemleri bitirilmiş olmaktadır. Hasta eğer vefat ederse, ölünün torbası (elbise ve para) hastane ambarında açılmadan tutularak Evkâf-1 Hümâyûn tarafindan görevlendirilecek mahkeme kâtibi kontrolünde, ölünün akraba ve yakınları huzurunda açılması gerekmektedir. Ölünün akraba ve yakınları yok ise hemşerilerinden birinin şahitliğinde torbası ambardan çıkartılarak para dışındaki eşyası müzayede ile satışı gerçekleştirilmektedir. Ele geçen meblağ, ölenin varisleri ortaya çıkana kadar

19 "Bir marîz arzuhâl edip nâzır bulunan zât tarafindan etıbbâya havâle ve etıbbâ dahi marîzin ahvâlini bi'l-muâyene hastahaneye idhâli îcâb eylediği hâlde cânib-i nezârete i'lâm ile ve i'lâm-1 mezkûre cânib-i nezâretden dahi duhûlü emr-i işaret ve târih vaz' olunarak marîz hastahâneye duhûl eylediği anda hastahâneden müfrez bir koğuşa dâhil olup elbisesiyle bir gece beytûtet eyledikde etıbbâ tarafından îcâb eden devâsı ve gıdas1 tahsîs olunup beytûtet eyleye ki neûzü billah tâûn ve yahud ale-1 sâiriyyeden bir illet ise diğer sâlim olan merzânın yanında konulmayıp ve tâûn olduğu halde tâûna mahsûs olan mahalle ve ale'l sâiriyyeden olduğu sûretde ale-l sâiriyye koğuşlarına idhâl oluna...” BOA. EV. d. 12552, 1261.C.18. [24 Haziran 1845]. 
hastane sandığında tutulmakta ve varisler ortaya çıkmazsa hesaptaki paralar, vakfın beytülmal hesaplarına gelir kaydedilmektedir. ${ }^{20}$

Hastalardan ölenlerle uğraşacak ilk personel elbette gassaldir. Ancak hastanenin açılıp hizmete girdiği 1847 yılındaki personel giderleri arasında gassal ve onun yardımcısına kadro olarak rastlamıyoruz. ${ }^{21}$ Zaten vakfiyede de gassal kadrosuna yer verilmemiştir. Ölen hastaların gasli (yıkanması) ve ölülere telkin vermeyi başlı başına bir gassallik kadrosu olarak değil, hastane camisinin imamına bir görev olarak verildiğini yine vakfiyeden öğreniyoruz. Vakfiyede geçtiği şekliyle ölü yıkama ve telkin görevi için imama, "hastane-i merkûmede olan hastalardan vefâtı tebeyyün eden olur ise ol ma'kûle, hastanın yanında oturup istiğfar ve kelimeteyn-i şehâdeteyni tezkir ve fevt [ölmüş̧] olanla-

20 "Gurebadan birisi marîz olup usûlü ve hastahâneye dâhil olduğunda elbise ve emvâl-i nakdiyyesini marîz kendi eliyle ve yahud gözü önünde bir torbaya idhâl edip ağzını iyice rabt etdikden sonra merbût olan hablın uçları müdîr-i hastahâne ve sertabîb ve imâm-1 hastahâne tarafından tahayyüz olundukdan sonra mühürleri bir yere cem' olunup bir küçük keseye vaz' olunarak hakkâklardan sekiz on paraya mühürler alınıp mürezânın ismine mutâbık bir mühürle mürezâ dahi torba-i mezkûru tahabbür etdikden sonra o mührü marîz bir ... ile ... ta'lîk eyleye ve marîzânın şifâsı müyesser olduğunda ser-tabîb hastanın himmetini cânib-i nezârete i'lâm ede ve i'lâm-1 mezkûr taraf-1 nezaretten dahi ihrâcını emr-i işaret ve tarih vaz' olundukda işbu i'lâm-1 sened alınarak hastahânede kalıp vakt-i hesâbda ibrâz oluna mezkûr hastanın gözü görür bir mahalde ta'lîk olunmağla üzerinde olan numrosu yatağının numrosuna mutâbık ve hastanın yedinde bulunan mühre dahi numro vaz' olunup üç numro tevâfuk eylediği halde marîz sıhhiyet ... huzûrunda torbanın küçük kesesinde olan mührü sahibinin yedinde olan mühre mutabık mıdır değil midir şahs-1 mezkûre irâe olunup diğer mühürler dahi birbirine dikkat ederek fek olunarak torbanın ağzı küşâd ve hasta emvâl ve eşyasını torba-i mezkûreden ahz eylediğini müş'ar bir sened i’ta edip imzaya kâdir ise kendisi değil ise hastahâne .. imza edip hastahânede hıfz oluna ve hastahâne malı olarak üzerinden çıkartılan melbûsât dahi me'mûru ma'rifetiyle tathîr olarak bohçasına konulub hastahâne elbisesi anbarına vaz' ve idhâl kılına. Ve bi-emrullahi teâlâ irtihâl-i dâr-1 bekâ etmiş ise torba-i mezkûr ta'lîk olunan mahalden ahz ve mühürleri dahi bozulmayarak hastahâne anbarında hıfz ve be-her mâh vakt-i hesâbdan Evkâf-1 Humâyûn tarafindan muayyen olarak bir kâtib'iş-şer' mâl-ı meyyitin akraba ve taallukâtı var ise huzurlarında yok ise hemşehrilerinden dahi bulunduğu halde defter edip ba'de'ttahayyüz hastahâne anbarında tevkîf ve terâkim eylediği halde çıkarıp bey'en yezîd müzâyede ve hâsıl olan meblağı defter-i muhâssasıyla beraber hastahâne sandığında hıfz ve vârisi zuhûr edip inde'ş-şer' verâseti tebyîn eylediği sûretde yalnız guruş bir para resm-i ahz olunarak vârise edâ oluna ve zuhûr etmediği halde Beyt'ül-mâl-i Vakf hazret-i müşârun ileyhâya âid olacağından meblağ-1 mezbûr cânib-i vakfi şerîfde zabt oluna.” BOA. EV. d. 12552, 1261.C.18. [24 Haziran 1845].

21 BOA. İ. MSM. 25/666. 
rın cenazelerini de'b-i ma'rûf üzre gasl [yıkama] ve ba'de-d defn telkîn [mezar başında dinî sözler söyleme] hizmetlerini edâ edüp mâhına [ayl1k] imamet içün altmış kuruş..."22 verilmektedir.

Gassal ve gassal yardımcısına, hastanenin ilk kurulduğunda ihtiyaç olmayacağı düşünülmüş; hastanenin yanındaki, hastane camisi olarak vakfedilen caminin imamı, ölü yıkama, defin ve telkin için yeterli görülmüş olmalıdır. Hatta caminin birinci ve ikinci imamlarına, sadece bu görevler değil, hastaların hastanede kaldıkları süre boyunca, nöbetleşe gece-gündüz şifa niyetine Yasin, Fetih, Mülk ve Nebe' sûreleri ile cüz okumaları da şart koşulmuştu. ${ }^{23}$

Vakfiyede kayıtlı olduğu üzere, her bir "imamet için altmış $k u$ ruş, ve yasinhanlık için on kuruş, ve fetihhanlık içün on kuruş ve mülkhanlık için on kuruş, ve nebehanlık için on kuruş, ve cüzhanlık için onbeş kuruş, ve kitabhane müstahfızlığı için on beş kuruş, ve gassallık mevta içün on kuruş, ve fodla bedeli otuz kuruş ki cem'an yüz altmış kuruş vazife " 24 belirlenmiş̧i. Hastane camisi imamları tarafından yerine getirilen gasl ve telkin işlerinin başlı başına gassallık kadrosu adı altında yerine getirilmesine 1853 y1lında rastliyoruz. ${ }^{25} \mathrm{O}$ ylldaki hastane toplam gideri 30.674 kuruş 36 paradır. Gassalin aylık maaşı 150 kuruş, hastanenin aylık personel giderinin de 15.430 kuruş olduğu düşünülürse gassalin personel giderleri içindeki oranı \% 1'dir. Ancak gassalin maaşı, tam 3 yıl sonra 1856 Ağustos'unda 250 kuruşa çıkacak ${ }^{26}$ ve bundan bir yıl sonra 1854 yılında 100 kuruş maaşla gassal yardımcısı da görevine başlayacaktır. ${ }^{27} 1879$ yılı başına gelindiğinde gassalin 250, gassal yardımcısının da 200 kuruş maaş alarak, 20.762 kuruş tutarındaki personel maaş giderleri içindeki ölüm işleriyle ilgili personel maaş giderleri oranının \% 2'ye çıkmış olduğunu göreceğiz. ${ }^{28}$

22 Vakfiye, s.325.

23 Vakfiye, s.323.

24 Vakfiye, s.324.

25 BOA. EV.d. 15123, 1269.Z.9. [14 Ağustos 1853].

26 BOA. EV.d. 16049, 1272.Z.11. [13 Ağustos 1856].

27 BOA. EV.d. 15552, 1271.S.21. [13 Kasım 1854].

28 BOA. EV.d. 24395, 1296.M.19. [13 Ocak 1879]. 
Hastane açıldıktan sonra ihtiyaca binaen ihdas edilen gassalin, hastane talimatnamesindeki ${ }^{29}$ görevlerine baktığımızda, her gün seher vaktinde hastanede bulunması gerektiğini görüyoruz. Ĕger cenaze varsa gassal, şer'î kurallara göre ölüyü yıkayıp kefenlenmesi, iyi bir insan olup olmadığının sorulması ve cenaze selâsından sonra, hizmetçi ile beraber mezarlığa kadar giderek ölünün defnedilmesini izleyerek telkin görevini yerine getirecektir. Ancak, cenazenin yıkandığ 1 yerin kapısından defnedilmesine kadar her türlü durumdan hastane cami imamının sorumlu olduğunu da görüyoruz.

Anlaşıldığı kadarıyla vakfiyede imamın görevleri arasında sayılan cenaze yıkama, kefenleme ve telkin işleri, başlı başına bir uzmanlık dalı olarak gassal kadrosunun ihdas edilmesiyle, bu görevlerin yeniden paylaştırılması söz konusu olmuştur. Talimatnamede, hizmetlerini tamamladıktan sonra hastaneyi terk ettikleri de belirtilmektedir. Nöbetçi doktor ile birlikte yirmi dört saat süre boyunca hastanede bulunacak olan gassalin nöbetteki görevi, can çekişmekte olan hastalara Kur'an okuyarak, hastane içinde ezan okuma görevlerini yürütmektir. Bunun yanında beş vakit namaz için camiye gelen cemaate imamlık yaparken, hastaların taburcu olma anında onlara dua ve Fâtiha-i şerîfe okuması zorunludur.

\section{Vakıf Gureba Hastanesi’nde Hastalık ve Ölümler}

XVIII. yüzyıl sonu Avrupa'sı için Lindemann'ın aktardığına göre ${ }^{30}$, doğan her 1.000 kişiden sadece 78 'inin yaşlılıktan ya da yaşlandiğında öldüğü, yani insanoğlunun en az onda birinin vakti dolmadan şans eseri öldügüu, daha açık bir ifadeyle ancak onda birinin yaşlılık günlerini görebildiği göz önüne alınırsa, ortalama yaşam süresinin biraz daha yükseldiği yarım yüzyıl sonrasına ait VGH'ye ait sınırlı belgeler çerçevesinde İstanbul'da bu denli bir ölüm oranına rastlanmadığını belirtmekte fayda vardır.

VGH, oluşturduğu Talimatname ${ }^{31}$ uyarınca hangi hastaların

29 Yildırım, 2013, s.274.

30 Mary Lindemann, Erken Modern Avrupa'da Tıp ve Toplum, (Çev. M. Doğan), Boğaziçi Üniversitesi Yayınevi, İstanbul 2013, s.25.

31 Yildırım, 2013, s.275. 
VGH'ye kabul edilip hangilerinin kabul edilmeyeceğini açıkça belirtmiştir. Buna göre, tedavi edilerek veya ameliyat yapılarak iyileşebilecek fakir ve garip hastaların hastaneye kabulü uygun bulunmuş; ebedî körlük, daimî sağırlık, kötürüm yatalak, bunak, abdal, mecnun ve miskin gibi çaresiz hastalıklara müptela olmuş hastaların hastaneye kabulünün yapılması da yasaklanmıştı.

Bu anlamda VGH'deki hastaların ölümü kolera gibi salgın hastalıklar nedeniyle olabileceği gibi, başka hastalıklar veya savaş sonrası göçlerden dolayı da olabiliyordu. Ölüm nedenlerine bakmak için seçilen ve altı aylık bir dönemin istatistiğini veren bir belge ${ }^{32}$, konunun anlaşılmasına biraz daha yardımcı olabilir.

1889 Eylülünden Şubat sonuna kadar olan altı aylık dönemde; Ağustos ayından Eylül ayına (1889) 238 hasta mevcuduyla geçilmiş ve 1890 Şubat ayı sonuna kadar hastanede toplam 3.948 kişiye tedavi işlemi yapılmıştır. Hastanenin altı aylık genel masrafları toplamı 429.515 kuruş olarak gerçekleşmiştir. 3.948 hastanın 3.186'sı iyileşerek hastaneden ayrılmış, 429'u tedavi esnasında ölmüş ve 65'i ise hastaneye getirilirken ya yolda veya hastaneye girerken vefat etmiştir. Altı ayın ölüm ortalaması, 82'yi geçmektedir. Altı aylık dönemin sonunda 1890 Mart ayına da 268 hasta ile geçilmiştir.

429 hastanın ölüm nedenlerinin 8'i yaşl1lıktan (şeyhûhet), 1'i frengiden, 28'i ameliyat esnasinda (emrâz-l cerrâhiye), 20'si bedensel rahatsızlıktan (emrâz- $\iota$ bünyeviyye), 94'ü bulaşıcı ve ateşli rahatsızlıklardan (emrâz-ı ihtimâriyye ve humeviyye), 3'ü ortopedik rahatsızlıktan (emrâz-ı hareket ve irâdet ve meşî), 8'i böbrek ve idrar hastalığından (emrâz-ı bevliye ve kilyeviyye), 78'i hazım yolları (emrâz-ı mecâri-i hazmiyye), 11'i kalp ve kan dolaşımı rahatsızlığından (emrâz-ı kalbiyye ve deverân-ı dem), 157'si göğüs rahatsızlığından (emrâz-l sadriyye) ve 21 'i de nörolojik ve psikiyatrik rahatsızlıktan (emrâz-ı dimâğıyye ve şevkiyye ve asabiyye) kaynaklanmıştır. Hastaneye getirilirken veya hastaneye giriş anında ölen 65 hastanın ölüm nedenine ilişkin herhangi bir açıklamaya rastlanılmamıştır.

32 BOA. Y. PRK. EV. 1.74, 1307.B.22. [14.03.1890]. 
Söz konusu altı aylık dönemde hastaneye gelen toplam 3.948 hastanın 3.186'sı iyileşerek taburcu olmuştur. Taburcu olan hastaların hastanede hangi rahatsızlıktan dolayı tedavi edildiğine gelince, on beş farklı rahatsılıktan dolayı hastaneden sağlı hizmeti aldıkları görülmektedir. Bunların 61'i hastaneye kabul edilip hiçbir tedavi sürecine tabi olmadan çıkmıştır. Hastane yönetmeliğ $i^{33}$ gereğince, hastanede yatmasına gerek kalmadan muayene edilip ilaçları verilerek gönderilmiş olabilir. 17 kişinin yaşlılık nedeniyle hastanede tedavi görerek taburcu oldukları anlaşılmaktadır. 13 kişinin sünnet olduğu kayıtlı olduğuna göre, çocukların da hastanenin hizmet verdiği kesim arasında yer aldığı görülmektedir. Bunu teyit eden diğer bir olay da, mezarcının küçük mezar başına 4 buçuk kuruş almasıdır. Buradan hareketle, hastanede çocuk hastaların pek eksik olmadığına hükmedebiliriz.

$\mathrm{Bu}$ dönemde hastanede; kanserden ölüm vakıasına rastlanılmamasına rağmen, 6 hasta kanser tedavisi görerek taburcu edilebilmiştir. Yine 188 frengi hastasından 1'i hariç tamamı, tedavi edilerek taburcu olmuştur. 101 kişi cilt rahatsızlığıyla hastanede tedavi görmüş ve tamamı iyileşerek ayrılmıştır. Altı ayda yapılan 304 ameliyatın 276'sı başarı ile sonuçlanarak taburcu edilmiştir. Bedensel rahatsılıktan dolayı hastaneye başvurarak tedavi gören 80 hastanın 20'si ölmüş, geri kalanı taburcu edilebilmiştir.

Hastanede en çok bulunan hastalar, bulaşıcı hastalık ve ateşli rahatsızlıklardan şikâyetçi olanlardır. Altı aylık dönemde gelen, iyileşerek giden veya ölen 3.680 hastanın 1.436'sı (\% 39), bu hastalık nedeniyledir. 1.436 hastadan 94'ünün, altı aylık sürede vefat ettiğine yukarıda değinmiştik. Nöbetli ve bağımlılıkla ilgili rahatsızlıklardan şikâyetle geri kalan hastanın 1.342'si de tedavi edilerek taburcu edilmiştir.

İdrar ve kalp rahatsılılı̆ı nedeniyle hastanede yatan 22 hastanın 8'i vefat etmiş ve geri kalan 14 hasta taburcu edilebilmiştir. Altı aylık dönemde, hazım yollarından yatan 485 hastanın $78^{\prime}$ 'i vefat etmiş, 407'si şifa bulup ayrılmıştır. Kalp ve kan dolaşımı rahatsızlıklarından şikâyetçi 38 hastanın 11'i vefat etmiş, geri kalan 27 hasta iyileşerek

33 BOA. EV. d. 12552, 1261.C.18. [24 Haziran 1845]. 
taburcu edilmiştir. Göğüs rahatsızlığ nedeniyle hastanede işlem gören toplam 698 hastanın 157'si vefat etmiş, geri kalan 541 hasta iyileşerek taburcu edilmiştir. Son olarak, menenjit ve sinir rahatsızlıklarından dolayı hastanede yatan 86 hastanın da 21'i vefat etmiş ve geri kalan 65 hasta ise iyileşerek hastaneden ayrılmıştır.

Altı aylık verilerin dikkate alındığı belgede, "geçmişte insanları hasta eden neydi" sorusunun cevabını daha ayrıntılı almak için, aylık bazda hastaların hangi hastalıktan kaç kişi ve ne oranlarda yattığına, hangi hastalıktan neden öldüğüne bakarak dönemin sağlık imkânlarını da anlamış olabiliriz. Aşağıdaki tabloda (Tablo 1) ${ }^{34}$, 1893 yılı Eylül ayı hasta sayısı ve hastalık adları, Ekim ayı ölüm sayısı ve hastaların hangi hastalıktan öldüğü ile Kasım ayı hasta sayısı ve hastalık adları yer almaktadır.

\begin{tabular}{|c|c|c|c|c|c|c|c|c|}
\hline$\stackrel{\varpi}{\mathscr{S}}$ & Çeşitli Hastalıklar & Emrâz-1 Mütenevvia & 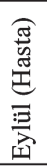 & 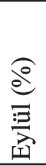 & 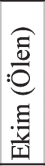 & $\begin{array}{l}\stackrel{0}{\varrho} \\
\vdots \\
: 0\end{array}$ & 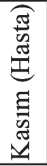 & 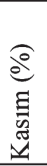 \\
\hline 1 & Akut beyin-omurilik zan iltihabı & İlthâb-1 sehâyâ-yı hâd & & & 3 & 6,5 & 2 & 0,8 \\
\hline 2 & Sinir ağrısı & Elem-i Asab & & & & & 1 & 0,4 \\
\hline 3 & Kalp kapakçığı hastalığı & Âfât-ı Dessâmiyye-yi kalb & & & 1 & 2,2 & 2 & 0,8 \\
\hline 4 & Akut bronş iltihabı & İltihâb-1 kasabât-ı hâd & 11 & 4,0 & & & 16 & 6,5 \\
\hline 5 & Kronik bronşit & İltihâb-1 kasabât-ı müzmin & 1 & 0,4 & & & 2 & 0,8 \\
\hline 6 & Akciğer şişmesi & İntifâh-1 ri'e & 3 & 1,1 & 2 & 4,3 & 1 & 0,4 \\
\hline 7 & İdrar (akıntı) & İdrâr & 5 & 1,8 & 5 & 10,9 & 2 & 0,8 \\
\hline 8 & Akut bağırsak iltihabı & İltihâb-1 em'â-i hâd & 8 & 2,9 & & & 8 & 3,2 \\
\hline 9 & Kronik bağırsak iltihabı & İltihâb-1 em'â-i müzmin & 3 & 1,1 & & & 3 & 1,2 \\
\hline 10 & Kurşunla ilgili hastalık & Elem-i usrubî & & & & & 1 & 0,4 \\
\hline 11 & Mîzaç bozukluğu & İnhirâf-ı mizâc & & & & & 4 & 1,6 \\
\hline 12 & Akkan iltihabı & İtihâb-1 lenfâiyye & & & & & 1 & 0,4 \\
\hline 13 & Akut eklem iltihabı & İltihâb-ı mufassal hâd & & & & & 1 & 0,4 \\
\hline
\end{tabular}

34 Tabloda verilen hastalık isimlerini (Emrâz-ı Mütenevvia) bugünkü dile "Çeşitli Hastalıklar" olarak çevirirken birkaç sözlükten faydalanılmıştır. Faydalanılan öncelikli eser, Ekrem Kadri Unat vd. (Haz.), Osmanlıca Tıp Terimleri Sözlüğ̈̈, Türk Tarih Kurumu, Ankara 2004, olmuştur. Bu sözlükte bulunmadığında ise M. Yahya Okutan vd. (Haz.) Yâdigâr-ı İbn-i Şerîf, İstanbul 2004; Ferit Devellioğlu, Osmanlıca-Türkçe Ansiklopedik Lûgat, Aydın Kitabevi Yayınları, Ankara 1996'dan yararlanılmıştır Yine bazı hastalıkların Osmanlıca okunmasında ise Sakarya Üniversitesi öğretim üyelerinden Doç. Dr. Mükerrem Bedizel Aydın ve Yrd. Doç. Dr. Ali Vasfi Kurt’tan yardım alınmıştır. 
15 Cild hastalığı

16 Akut ve kronik bağırsak iltihabı

17 Hazımsızlık

18 Mide hazımsızlığı

19 Karaciğer sirozu

20 Güneș çarpması

21 Sitma zehirlenmesi

22 Şiddetli ezik

23 Kesici yarası

24 Ezik yarası

s1

5 Hastalıktan kaynaklı/Keskin yara

26 İdrar torbası ateşi

27 İyileșen sıtma ateșlileri

28 Tifo

29 İdrar yurtığı

30 Sünenetsizlik çıbanı

31 Filogmani (iltihab)

32 Eklem çıkığı

33 Frengili erkek testisi

34 Akut dizanteri

35 Dizanteri

36 Siraca (beze veremi)

37 Akciğer iltihabı, zatüre

38 Akciğer ve zarının iltihabı

39 İdrar yırtığı ateși iltihabı Akciğer zarının sıvı

40 toplanmasıyla özellenen iltihabı

41 Eklem romatizması

42 Çok eklem romatizması? Sitmadan kaynaklanan ileri

43 derece zayıflık?

44 Sivilceli (irinli) kanser

45 İç kulak akıntısı

46 Yaşlilık

47 Kalp büyümesi

48 Dalak büyümesi

49 Frengi hastalığ

(int

50 Deve huylu (kinci) kangren

51 Bel altı (așağı taraf) felci

52 Felç

53 Sitmadan kaynaklanan kansızlık

54 Güçsüzlük ülseri (yara)

55 Başlangıç frengi ülseri

56 Gözetim altında

57 Salgın nezle (grip)

58 Bâsûr

59 Eklem şişliği

İtihâb-1 mufassal müzmin

Emrâz-1 cildiyye

İltihâbı em'â-i hâd ve

müzmin

Tuhme

Tuhme-i mi'dî

Teşemmu'-1 kebed

Teșmîs

Tesemmüm-ü merzagî

Tardîd-i şedîd

Cerha-i kâtı'a

Cerha-i radiyye

Cerha-i azb

Hümmeyât-1 mesânî

Hümmeyât-1 merzagî ber'

Hummâ-yı tifoidî

Mezk-ul bevl

Hurâc-1 hitânberî

Hurâc-1 Filogmani

Hal'ı mafsal

Hayâ-u racul-u efrencî

Disentarya-i hâd

Disentarya marazı

Dâ-ül-Hanâzîr

Zât-ür-ri'e

Zât-ül-cenb ve'r-ri'e

Zât-ül hummâ-yı mezk-ul

bevlî

\begin{tabular}{|l|l|l|l|l|l|} 
& & & & 2 & 0,8 \\
& & & & 2 & 0,8 \\
& & 10 & 21,7 & 2 & 0,8
\end{tabular}

\begin{tabular}{|c|c|c|c|c|c|}
\hline 36 & 13,2 & & & 10 & 4,0 \\
\hline & & & & 3 & 1,2 \\
\hline & & 1 & 2,2 & & \\
\hline
\end{tabular}

\begin{tabular}{|c|c|c|c|c|}
11 & 4,0 & & 11 & 4,4 \\
\hline & & & 1 & 0,4 \\
\hline & & & 2 & 0,8 \\
\hline
\end{tabular}

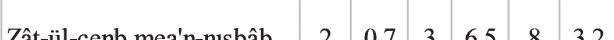

Resye-i mafsaliyye

Resye-i kesîr-ul mafâsıl

\begin{tabular}{l|l}
7 & 2,6 \\
\hline & 1
\end{tabular}

\begin{tabular}{l|l|l}
2 & 0,8
\end{tabular}

\begin{tabular}{|l|l|l|l|l|}
\hline 3 & 1,1 & 4 & 1,6 \\
\hline 3 & 1,1 & & 3 & 1,2 \\
\hline
\end{tabular}

\begin{tabular}{|l|l|l|l|l|l|}
\hline 3 & 1,1 & & & 3 & 1,2 \\
\hline
\end{tabular}

\begin{tabular}{|c|c|c|c|c|c|}
\hline & & 1 & 2,2 & & \\
\hline 99 & 36,3 & & & 40 & 16,1 \\
\hline 1 & 0,4 & & & 14 & 5,6 \\
\hline
\end{tabular}

\begin{tabular}{l|l|l|l|l|}
1 & 0,4 & 14 & 5,6
\end{tabular}

\begin{tabular}{l|l|l|l|l|l|}
5 & 1,8 & 1 & 2,2 & 6 & 2,4 \\
\hline
\end{tabular}

\begin{tabular}{l|l|l|l|l|l|}
1 & 0,4 & 1 & 2,2 & 1 & 0,4 \\
\hline
\end{tabular}

(1)

\begin{tabular}{|l|l|l|l|l|l|}
\hline & & & & 2 & 0,8 \\
\hline & 3,3 & & & 6 & 2,4 \\
\hline & & 2 & 4,3 & & \\
\hline & 1,5 & & & 9 & 3,6
\end{tabular}

\begin{tabular}{|l|l|l|l|l|l|}
\hline 4 & 1,5 & 2 & 4,3 & & \\
\hline 5 & 1,8 & 3 & 6,5 & 8 & 3,2 \\
\hline
\end{tabular}

Su-i'l kınye-i merzagî

Seretân-ı büsrevî

Seyelân-1 üzün-i fỉhi

Şeyhûhet

Dahâme-i kalb

\begin{tabular}{|l|l|l|l|l|}
\hline 4 & 1,5 & & 12 & 4,8 \\
\hline & 0,4 & & 1 & 0,4 \\
\hline
\end{tabular}

$\begin{array}{ll}4 & 1,5 \\ 1 & 0,4\end{array}$

\begin{tabular}{l|l|l}
1 & 0,4
\end{tabular}

Dahâme-i thhâl

İlet-i efrenciye

\begin{tabular}{|l|l|l|l|l|l|}
\hline 4 & 1,5 & 4 & 8,7 & 6 & 2,4 \\
\hline
\end{tabular}

Gangren-i şütur-hû(y)

Felc-i esfel

Felc

Fakr-1 dem-i merzagî

Karha-i vehniye

Karha-1 efrenciye-i evvelî

Mülâhaza tahtında

Nezle-i müstevliye

Nâsûr-1 1hlîl havl-üș-șerc

Verem-i ebyaz

\begin{tabular}{|l|l|l|l|l|}
\hline & 1 & 2,2 & 2 & 0,8 \\
\hline
\end{tabular}

\begin{tabular}{|l|l|l|l|l|l|l|}
\hline 3 & 1,1 & & & 3 & 1,2 \\
\hline
\end{tabular}

TOPLAM

\begin{tabular}{|l|l|l|l|l|l|}
\hline 273 & 100 & 46 & 100 & 248 & 100
\end{tabular} 
Buna göre hastanedeki (Eylül, 1893) 273 hastasının 99'unu (\% 36,3) sıtma ateşlileri oluşturmaktadır. Sağlık alanında en büyük kronik sorunlardan biri olan sıtmanın başta gelen nedeni bataklıklardır. Sitma humması veya ateşi, bilinen en uzun ömürlü ve en ölümcül hastalıktı. 1567-68 yılı Floransa'sındaki (İtalya) San Paolo Hastanesi'nde, erkek hastalar arasındaki teşhis kategorileri içinde humma, \% 60'lar düzeyindeydi. ${ }^{35}$ Tarihin başlangıcından beri, gezegenimizde ölen erkek, kadın ve çocukların yarısı sıtmanın kurbanı olmuştu. Tüm bulaşıcı hastalıklar içinde insanoğluna en büyük zararı sıtma vermişti. ${ }^{36}$ XXI. yüzyıla kadar Türkiye topraklarını terketmemesine karşın sıtma, Avrupa'da XVIII. yüzyılda gerilemeye başlamıştı. Bu tarihe kadar bataklıkların çoğunu kurutmuş, sivrisinekler için üreme alanı olan ormanların çoğunu yok etmişlerdi. Topraktaki bu değişiklikler ve daha iyi havalandırılan evlerin inşası, Avrupalıları sivrisineklerden ve ateşli hastalıklardan uzaklaştırmıştı. ${ }^{37}$ 1770-1800 arası dönemi Edinburgh Kraliyet Kliniği'ndeki teşhis kategorileri içinde sıtma ateşi veya ateş nöbetleri \% 2'yi bulmamaktadır. ${ }^{38}$

Oysa 1893 Eylülünde İstanbul'un asıl uğraştığı mesele, kolera salgınıydı. Hükümet birçok noktada kolera salgınına karşı karantina uygulamalarına başvuruyordu. ${ }^{39}$ İzmir'de Eylül ayında ortalama 1,5 insan koleradan ölürken, ${ }^{40}$ Üsküdar'da Eylül-Kasım arası kolera salgını vakası 35-40 arasında değişmektedir. ${ }^{41}$ Suriçi'nde (Fatih ve Eminönü) Kasım ayı kolera vakası 400'ü geçerken ${ }^{42}$ VGH'de bu hastalığa aynı ay içinde hiç rastlanmaması ilginç gözükmektedir.

35 John Henderson, The Renaissance Hospital: Healing the Body and Healing the Soul, New Haven 2006, s.266.

36 Andrew Nikiforuk, Mahşerin Dördüncü Atlısı: Salgın ve Bulaşıcı Hastalıklar Tarihi, (Çev. S. Erkanlı), İletişim, İstanbul 2010, s.34.

37 Nikiforuk, a.g.e., s.41.

38 Guenter Risse, Hospital Life in Enlightenment Scotland: Care and Teaching at the Royal Infirmary of Edinburgh, Cambridge 1986, s.120-121.

39 Ayar, a.g.e. s.43.

40 Ayar, s.97.

41 Ayar, s. 159.

42 Ayar, s.165. 
Kontrol edilebilen sıtma ateşinden sonra Eylül ayında görülen ikinci hastalık, 36 ile hazımsızlıktır (\% 13,2). Sayı olarak üçüncü sırayı oluşturmasına rağmen ayrıntılı bilgi verilmeyen ve fakat sadece gözetim altında bilgisi ile hastaların \% 5,5'ini oluşturan sıtma ateşinden sonraki sırayı frengi (13 hasta ile \% 4,8), akut bronş iltihabı (11 hasta ile \% 4) ve güneş çarpması (11 hasta ile \% 4) oluşturmaktadır.

Ekim ayında 46 ölümle sonuçlanan hastalıkların ilk üç sırasını akut ve kronik bağırsak iltihabı (10 ölüm ile \% 21,7), idrar (5 ölüm ile $\% 10,9$ ) ve sitmadan kaynaklanan ileri derece zayıflk (4 ölüm ile \% $8,7)$ oluşturmaktadır. Sonraki sırayı ise 6 ölüm ile $(\% 6,5)$ üç hastalık paylaşmaktadır: beyin-omurilik zarı iltihabı, akciğer iltihabı (zatüre) ve akciğer zarının sivı toplanmastyla özellenen iltihabı.

Kasım ayındaki hastalıklara baktığımızda, Eylül ayı hastalıklarından farklı olarak tifonun üçüncü sırayı kapladığı görülmektedir. Eylül ayında bir hastanın tifodan hastanede yattı̆̆ına bakılırsa, Kasım ayında sayının 14'e yükselmesi dikkat çekmektedir. Koleranın da bu ayda İstanbul Suriçi'nde 400'ü bulmasından anlaşıldığı kadarıyla; sıtma, tifo, kolera ve dizanteri gibi VGH'nin en çok karşılaştığı hastalıkların bataklık ve pis sulardan bulaşan/kaynaklanan hastalıklar olması, Osmanlı başkentinin söz konusu dönemde de temiz su sorununu çözemediğini akla getirmektedir. ${ }^{43}$

Eylül ve Kasım ayında hastanede yatan hasta sayısı ortalaması 260 olup, Ekim ayında ölen hasta da 46' dır. Buna göre aylık ölüm ora$\mathrm{n} 1$ ise yaklaşı \% 17,7' dir. Balıklı Rum Hastanesi'nin 1833-1860 arası 27 yılın sonbahar aylarının ölüm oranı ortalaması ise \% 29'dur. Sebebi büyük ölçüde Yedikule Hastanesi’nde tedavi görenlerin çoğunun çiftliklerde, tarlalarda ve bataklık bölgelerde yaşıyor olmasıdır. ${ }^{44}$

Söz konusu Eylül, Ekim ve Kasım (1893) aylarındaki hem hastalık, hem de ölüm teşhisleri arasında sıtmanın dışında sayılanların sayıca fazla olanları da, sıtmadan kaynaklanan başka tanılar olabileceği düşünülebilir. Çünkü sıtma, çoğunlukla bünyeyi zayıflatmakta, kansız-

43 Aleksandros Paspatis, Balıklı Rum Hastanesi Kayıtlarına Göre İstanbul'un Ortodoks Esnafı 1833-1860, (Çev. M. Yerasimos), Kitap Yayınevi, İstanbul 2014, s.23.

44 Paspatis, a.g.e., s.51. 
lığa yol açmakta, bağışıklık sistemini çökertmekte, tifo, grip, dizanteri ve kötü beslenme gibi başka hastalıklara yol açabilmektedir. ${ }^{45}$ Hatta hazımsızlık ve güneş çarpması gibi rahatsızlıklar da bu çerçevede değerlendirilebilir. Bu açıdan sıtma dışı tanıların önemli bir kısmını sıtma türevi rahatsızlık olarak görecek olursak, sıtmanın sanıldığından daha büyük bir sorun, yüzyıllardır çözülememiş bir sorun olageldiği görülür.

Servet-i Fünûn dergisinde çıkan haberler ve yazılar sorunun aydın kesiminde de tartışıldığını ve gündem olduğunu göstermektedir. Örneğin 1893 Ağustos ayında ${ }^{46}$ Kadri'nin Artezyen Kuyularl adlı altı sayfalık uzun makalesi bu konuyu işlerken, yine aynı sayıda Dersaadet sularının bakteri üretip üretmediği ile ilgili araştırma ve uygulama yapmak üzere Mekteb-i Tibbiye-i Şâhâne'de bir ameliyathanenin tesis edileceği bilgisine yer verilmektedir. ${ }^{47}$ Neredeyse her sayısında, haberlerin ilk konusunun tıbbiye ve sıhhiye üzerine oluşu da, düşüncemizi destekler niteliktedir. Haberlerde su, temizlik, mikroplar, pisliklerin yol açtığı hastalıkların tedavi yöntemleri veya hastalıklar için hükümetin aldığı tedbirler sıklıkla vurgulanmaktadır. ${ }^{48}$

\section{Vakıf Gureba Hastanesi’nde Ölüm ve Ölüme İlişkin Masraflar}

VGH yatak kapasitesinin 1892'de 300'e çımasının sebebi, elbette hasta yoğunluğunun artmasıyla açıklanabilir. Hastane istatistik cetveline ${ }^{49}$ göre, 300 yatak kapasitesine çıkmasından bir yıl sonra 1893 'te, Ağustos'tan Eylül ayına devreden 273 hasta ve Ekim ayı içinde gelen 445 hasta ile bu sayının 718'e çıktığını görüyoruz. 718 hastanın 347'si şifa bulup hastaneden ayrılırken, geriye kalan 371 hastadan 46'sının da tedavi esnasında öldüğüne şahit olunmaktadır.

45 Nikiforuk, a.g.e., s.34.

46 Kadri, “Artezyen Kuyularl”, Servet-i Fünûn, İstanbul, 19 Ağustos 1309 [31 Ağustos 1893], C.5, S.129, ss. 387-393.

47 Mevâdd-1 Tibbiye ve Sihhiye, Servet-i Fünûn, 19 Ağustos 1309 [31 Ağustos 1893], C.5, S.129, s.400.

48 Mevâdd-1 Tibbiye ve Sihhiye, Servet-i Fünûn, 9 Eylül 1309 [21 Eylül 1893], C.6, S.132, s.23-24 ve 32; Dersaadet Anadolu Ciheti Suları, Servet-i Fünûn, 16 Eylül 1309 [28 Eylül 1893], C.6, S.133, s.42-44; Mikroplar, Servet-i Fünûn, 12 Teşrinievvel 1309 [24 Ekim 1893], C.6, S.138, s.128; İskambil Kağıdları ve Mikroplar, Servet-i Fünûn, 19 Teşrinievvel 1309 [31 Ekim 1893], C.6, S.139, s.130-133.

49 BOA. EV. D. 28077, 1311.Ra.3, [14 Eylül 1893]. 
Geriye kalan 257 hastanın 9'u da hastaneye getirilirken yolda veya hastaneye tam giriş anında ölmüştür. Bu sayıyı da bir ayda hastanede ölenlerin sayısına eklediğimizde hasta ölüm oranının \% 7,7'ye çıkması, ölümün ender oluşuna zıtlık teşkil etmektedir. Nihayetinde Kasım ayına 248 yataklı hasta ile geçilmektedir.

Hastanenin ölüm masrafları maaş, tayınat, ecza ve çeşitli giderler (araç-gereç vs.) kadar değilse bile, hesaplarda ayrı bir başlıkta değerlendirilecek kadar bir yekûnu oluşturmaktadır. Aşağıdaki tabloda (Tablo 2), 1860 ila 1872 arasındaki bazı aylarda hastanenin aylık toplam gideri ile bu giderler içindeki ölüm giderleri, ölüm sayıları, ölüm gideri oranları ve bir kişinin hastaneye ortalama ölüm maliyeti görülmektedir.

Tablo 2: Vakuf Gureba Hastanesi Ayllk Giderleri ve Ölüme İlişkin Veriler (1860-1872)

\begin{tabular}{|l|c|c|c|c|c|}
\hline \multicolumn{1}{|c|}{ Y1l - Ay } & $\begin{array}{c}\text { Ölüm } \\
\text { Gideri } \\
\text { (Kuruș) }\end{array}$ & $\begin{array}{c}\text { Toplam } \\
\text { Gider } \\
\text { (Kuruș) }\end{array}$ & $\begin{array}{c}\text { Ölüm } \\
\text { Gideri } \\
\text { Oranı (\%) }\end{array}$ & $\begin{array}{c}\text { Ölen } \\
\text { Kişi } \\
\text { Say1S1 }\end{array}$ & Kiși Baş1 Ölüm \\
\hline 1860 Eylül & $1.159,8$ & $43.175,3$ & 2,68 & 37 & 31,34 \\
\hline 1860 Kasım & $1.159,8$ & $45.200,0$ & 2,56 & 50 & 25,65 \\
\hline 1862 Kasım & $1.890,8$ & $38.409,6$ & 4,92 & 57 & 33,17 \\
\hline 1862 Aralık & $2.757,0$ & $45.157,4$ & 6,10 & 78 & 35,34 \\
\hline 1864 May1s & $2.980,5$ & $49.811,9$ & 5,98 & 70 & 42,57 \\
\hline 1872 May1s & $1.832,5$ & $54.000,9$ & 3,39 & 61 & 30,04 \\
\hline
\end{tabular}

Kaynak: BOA. EV.d: 17216, 1277.S.26; 17269, 1277.R.28; 18069, 1279.C.19; 18071, 1279.C. $20 ; 18911,1280 . Z .06 ; 22369,1289$. Ra.05.

Hastanenin ölüm ile ilgili personellerinin (gassal ve gassal yardımcısı), personel giderleri içindeki oranın artışına paralel olarak, hastanede ölen sayısındaki artış kadar, ölüm masrafları ve ölüm masraflarının toplam giderler içindeki oranı da artış eğilimindedir. Ölü sayısının bazı aylarda başlangıç seviyesinin iki katına kadar çıkmasının sebebi, o yıllarda sıkça rastlanan salgın hastalıklardan kolera olabileceği gibi başka hastalıklar da olabilir. ${ }^{50}$

Tablo 2'de, 1860 yılı Eylül ayında 37 hastanın öldüğü ve ölüm

50 Bkz. Y1ldırım, 2010, s.75; Ayar, 2007. 
giderleri toplamının da $1.159,8$ kuruş (1.159 kuruş 30 para) olduğu görülmektedir. Hastanenin 43.175,3 kuruş tutarındaki aylık toplam giderinin \% 2,68'i, sadece ölenlere ilişkin yapılan harcamaların oranıdır. 1872 yılı Mayıs ayında, toplam harcamalar içindeki ölüm giderleri oranı \% 3,39'a yükselmiştir. 1860 yılı Eylül ayından 1872 Mayıs'a kadar olan dönemdeki toplam harcamaların (43.175,3'ten 54.000,9 kuruşa) artış1 \% 25 oranında gerçekleşmişken, aynı dönemdeki ölüm giderlerindeki (1.159,8'den 1.832,5 kuruşa) artış \% 58'i bularak, ölüm giderlerindeki artış, toplam harcamaların artış hızından daha fazla bir artış eğilimine girmiştir.

Üzerinde durduğumuz husus, ölümün mali tarafı olduğu için Tablo 2'deki hem ölüm giderinin, hem de ölen kişi sayısının en yüksek olduğu 1862 Aralık ve 1864 Mayıs ayı verilerine daha ayrıntılı bakmakta fayda vardır.

1862 Aralık ayı ölüm giderlerinin ayrıntısını gösteren tablo (Tablo 3) aşağıda verilmiştir. Bu tabloya göre hemen hemen her ay tekrarlanan dokuz farklı gider kalemi, hastanenin ölüm masrafları yekûnunu oluşturmaktadır.

Tablo 3: Vakıf Gureba Hastanesi'nde Ölenlere İlişkin Ayrıntılı Gider Unsurlarl (1862 Aralık)

\begin{tabular}{|l|c|c|c|c|c|c|}
\hline Gider Türleri & Kuruş & Kıyye & Top & Zira & $\begin{array}{c}\text { Ölen } \\
\text { (Kiși) }\end{array}$ & $\begin{array}{c}\text { Birimi } \\
\text { (Kuruş) }\end{array}$ \\
\hline Kefenlik Hassa Bezi & 1.599 & & 19,5 & & & 82 \\
\hline Sabun & 30 & 5 & & & & 6 \\
\hline Pamuk & 48 & 2 & & & & 24 \\
\hline Gülsuyu & 16 & 2 & & & & 8 \\
\hline Lifli Tütsü & 30 & & & & \\
\hline Kâfûrî & 5 & & & & & \\
\hline İplik & 3 & & & & \\
\hline Setr Bezi & 12 & & & 8 & & 1,5 \\
\hline Mezarc1 & 1.014 & & & & 78 & 13 \\
\hline Toplam Ölüm Gideri & 2.757 & & & & \\
\hline Kaym: BOA. EV & & & & \\
\hline
\end{tabular}

Kaynak: BOA. EV.d. 18071, 1279.C.20. 
En büyük masraf kalemini, 1.599 kuruş ile kefenlik bez oluşturmaktadır. Bir topu 82 kuruş olan bezden, söz konusu ayda 19 buçuk top bez kullanılmıştır. Giderlerin ikinci büyük kalemi, mezarcıya yapılan ödemedir. İnsan gücü ile kazılan her bir mezar için mezarcıya 13 kuruş üzerinden toplam 1.014 kuruş ödeme yapılmıştır. Ancak mezarcıya verilen ücretin tek bir kişiye mi, yoksa daha fazla kişiye mi yapıldığ belirtilmemiştir. Kayıtlarda, aynen tablolarda verildiği gibi mezarcl olarak gider türlerinde belirtilmiştir.

Aynı tarihte hastane müdürünün 1.200, müdür yardımcısının 600, hastane camisi hizmetçisinin 1.000, tabib-i evvelin 3.000, tabib-i sânînin 2.000, tabib-i sâlis, tabib yardımcısı, eczâc1-1 evvel ve kâtib-i evvelin 750, cerrâh-1 evvelin 500, cerrâh-1 sânî, elbise emîni ve vekilharcın 400'er kuruş maaş aldığ düşünülürse, mezarcının aylık gelirinin 1.014 kuruşu bulması anlamlı olsa gerektir. Tabib-i evvel, tabib-i sânî ve hastane müdüründen sonra hastaneden maaş veya gelir elde etmede dördüncü sırada yer alan mezarcının emek gücünün, hastane için çok pahalıya mal olduğu bir gerçektir.

Ancak bu durum, iki yıl içinde fark edilerek mezarcıya yapılan ödemenin görece fazlalığına, 1864 yılı Eylülünde bir neşter vurulmuş gibidir. Görüldüğü kadarıyla çözüm, ölen hastanın büyük, orta ve küçük sınıflamasına tabi tutularak, ödemenin de bu çerçevede yapılması olacaktır. Ölen hasta büyükse 18 kuruş, orta uzunlukta ise 9 kuruş ve küçükse 4 buçuk kuruş ödeme yapılacaktır. Nitekim 1864 Eylülünde, 25 büyük (uzunluk anlamında) ölü için 450 kuruş, 15 orta uzunlukta ölü için 135 kuruş ve 23 küçük ölü için de 103 buçuk kuruşluk ödeme ile toplamda 63 ölü mezarı için mezarcıya 688,5 kuruşluk ödeme yapılacaktır. ${ }^{51}$ Küçük mezar için belirtilen 23 sayısından, bu ölümlerin çocuk veya bebek ölümü olabileceğini düşünmek durumundayı.

Üçüncü büyük gider kalemi pamuktur. Kıyyesinin (1.280 gram veya 400 dirhem) 24 kuruş gibi oldukça yüksek fiyattan satın alındığı pamuktan aylık ortalama 2 kıyye harcanarak, hastanenin 48 kuruşluk pamuk gideri olmaktadır. Sabun, gülsuyu, tütsü ve kâfûrî gibi temizlik ve güzel koku veren malzemelere yapılan harcamalardan da (81 kuruş)

51 BOA. EV.d. 19208, 1280 Teşrînievvel. [Eylül 1864]. 
geri durulmadığı görülmektedir. Örtü bezi ve iplik giderleri de, her ay tekrarlanan ölüm giderleri kalemleri arasında yerini almaktadır.

1862 Aralık ayı ölüm giderlerini ayrıntılı bir şekilde inceledikten sonra, söz konusu gider kalemlerini, 1864 Mayısı ölüm gideri kalemleri ile karşılaştırabiliriz. 1864 Mayıs ayı ölüm giderlerinin ayrıntısını gösterir tablo (Tablo 4) aşağıda verilmiştir.

\begin{tabular}{|c|c|c|c|c|c|c|c|}
\hline Gider Türleri & Kuruş & Kiyye & Dirhem & Top & Zira & \begin{tabular}{|c|} 
Ölen \\
(Kişi)
\end{tabular} & $\begin{array}{c}\text { Birimi } \\
\text { (Kuruș) }\end{array}$ \\
\hline Kefenlik Hassa Bezi & 1.575 & & & 17,5 & & & 90 \\
\hline Sabun & 27 & 4,5 & & & & & 6 \\
\hline Penbe (Pamuk) & 49 & 1 & 300 & & & & 28 \\
\hline Gülsuyu & 14 & 1 & 300 & & & & 8 \\
\hline Lifli Tütsü vs. & 32 & & & & & & \\
\hline \multicolumn{8}{|l|}{ Kâfûrî } \\
\hline İplik & 2,5 & & & & & & \\
\hline Setr Bezi & 15 & & & & 7 & & 2,14 \\
\hline Mezarc1 & 1.260 & & & & & 70 & 18 \\
\hline Toplam Ölüm Gideri & $2.980,5$ & & & & & & \\
\hline
\end{tabular}

Kaynak: BOA. EV.d. 18911, 1280.Z.06.

1864 yılı Mayıs ayına ait hastane aylık ölüm masrafının en büyük kalemini, 1.575 kuruş ile yine kefenlik bezi oluşturmaktadır. Önceki tabloya (Tablo 3) göre 8 ölünün az olduğu bu ay için 2 top daha az kefenlik bezine ihtiyaç duyulmuştur. Buna göre bir top kefenlik bezi, 4 ölünün kefenlenmesine yetmektedir. $\mathrm{Bu}$ arada, yaklaşık bir buçuk y1l sonra kefenlik bezinin 82 kuruştan 90 kuruşa çıkarak, bir topuna 8 kuruşluk zam geldiğini görüyoruz.

Giderlerin ikinci büyük kalemi, bir buçuk yıl önce (1862 Aralık) olduğu gibi, yine mezarcıya yapılan ödemedir. İnsan gücü ile kazılan her bir mezar için mezarcıya bu sefer, 13 kuruş yerine 18 kuruş üzerinden toplam 1.260 kuruş ödeme yapılmışıtır. Hem kefenlik bezinin, hem de mezarcıya her mezar yeri kazımı için ödenen fiyatlar \% 10 ve $\% 46$ oranında artarken, hastanenin yukarıda sayılan ve diğer tüm personellerinin maaşının olduğu gibi yerinde sayması, muhtemeldir ki 
hastane personelinin itirazına sebep olmuştur. Hastane müdürü 1.200 kuruş maaş alırken, mezarcıya yapılan aylık mezarlık işleri için yapılan ödemenin 1.260 kuruşu bulması bir yana, mezarcının hastane müdüründen 60 kuruş fazla alması, mezarcıya yapılan ödemelere bir çeki düzen verilmesini gündeme getirmiş olmalıdır.

Yukarıda değinildiği gibi, mezarcıya 1864 Eylülünden itibaren, ölen hastanın büyüklüğüne göre üç farklı şekilde ödeme yapılacaktır; büyük, orta ve küçük mezar kazımı. Büyük mezara 18 kuruş, orta mezara 9 kuruş ve küçük mezara da 4 buçuk kuruş ödenecektir. Dikkat edilirse, bu düzenlemeden önce, bütün ölüler için mezarcıya yapılan ödemenin aynı, 18 kuruş olduğunu ve diğer mezarlıklar için de o fiyatın baz alındığı görülmektedir. Yani, mezarcıya yapılan ödemelerdeki artıştan geri adım atılamamaktadır. Buradan da, kamu görevlisi olarak kabul edilen hastane personellerinin maaşlarının, piyasadaki ücret-fiyat artışları karşısında yerinde saydığını söyleyebiliriz.

Tablo 3'den farklı olarak 1864 Mayısında kâfurîye (camphre) ihtiyaç olmamıştır. Sabun ve gülsuyunun fiyatı yerinde sayarken, pamuğun 4 kuruş zamlandığ1 görülmektedir. Tablo 2'de dönemin sonu olan 1872 Mayıs ayı ölüm giderlerine, aşağıdaki tablodan (Tablo 5) ayrıntılı bakacak olursak, bazı gider kalemlerinin yer almadığını, yerine başka bir giderin yapıldığını görmekteyiz.

Tablo 5: Vakıf Gureba Hastanesi'nde Ölenlere İliskkin Ayrtntılı Gider Unsurlarl (1872 Mayls)

\begin{tabular}{|l|c|c|c|c|c|c|c|}
\hline Gider Türleri & Kuruş & Kiyye & Dirhem & Top & Zira & $\begin{array}{c}\text { Ölen } \\
\text { (Kişi) }\end{array}$ & $\begin{array}{c}\text { Birimi } \\
\text { (Kuruș) }\end{array}$ \\
\hline Kefenlik Hassa Bezi & 652 & & & 11 & 36 & 56 \\
\hline Penbe (Pamuk) & 30,5 & 1 & 610 & & & & 20 \\
\hline Gülsuyu & 10,7 & 1 & 610 & & & & 7 \\
\hline Lif & 15,3 & 1 & 305 & & & & 20 \\
\hline Kâfûrî & 9,2 & & 91,5 & & & & 40 \\
\hline İplik & 12 & & & 4 & & 3 \\
\hline Günlük & 4,6 & & 305 & & & & 6 \\
\hline Mezarc1 & 1.098 & & & & & 61 & 18 \\
\hline
\end{tabular}

$\begin{array}{ll}\text { Toplam Ölüm Gideri } & 1.832,5\end{array}$

Kaynak: BOA. EV.d. 22369, 1289.Ra.05. 
Önceki tarihlerde giderler arasında sayılan sabun ve setr bezini, 1872 Mayıs ayında göremiyoruz. İhtiyacın olmadığına, ya da elde yeterli düzeyde sabun ve setr bezinin olduğuna hükmedebiliriz. Yeni gider kalemi olarak günlük dikkatimizi çekmektedir. Kıyyesi 6 kuruş olan günlüğe 305 dirhem kadar ihtiyaç duyulmuş ve buna karş11ı 4,6 kuruşluk bir gider yapılmıştır. Gider kalemleri arasında en büyük masraf, kefenlik hassa beziydi. Bu dönemde bezin bir topunun 56 kuruş ve ziraının da 1 kuruş olduğunu görüyoruz. Kefenlik bezin, 1860 yılındaki fiyatının 82 kuruş, daha sonra 1864 Mayısında 90 kuruşa çıktığı düşünülürse, 56 kuruşa kadar düşüşü, pamuğun da aynı şekilde başlangıçta kıyyesi 24 kuruş, sonra (1864 Mayıs) 28 kuruş, dönem sonunda da (Tablo 5) 20 kuruşa kadar düşüşü ile aynı nedenlere sahip olsa gerek.

Kefenlik bezindeki keskin düşüşe paralel olarak söz konusu yıllarda İngiliz pamuklu dokumalarının Osmanlı pazarındaki etkisinin giderek artışını hatırlamak yerinde olacaktır. ${ }^{52}$ İngiliz sanayisinin 1790'lardan itibaren uyguladığı maliyet düşürücü yeni yöntemler neticesinde (100 numara çile poundu 38 shilling iken 1792'de 16'ya düşmüştü) Halep, Şam, İzmir, Bursa ve İstanbul pamuklu sanayisinin girdileri, İngiliz pamuk ipliklerine dayanıyordu..$^{53}$ Osmanlıdaki bez pazarının İngiliz malları tarafından ele geçirilişi XIX. yüzyılın ortalarından sonradır. İngiltere'den Osmanlı'ya 1825-1860 yılları arasında yapılan pamuklu ihracat seyrine baktığımızda, fiyatların düşüşünü açıklayabilecek bir eğilimin ortada olduğu görülür. 1825 'te $3.578,1830$ ' da $15.940,1835$ 'de $25.692,1845$ 'de 46.793 , 1850'de 31.124, 1855'de yaklaşı beş kat artışla 132.605 ve 1860 'ta \% 73 artışla 229.201 bin yarda pamuklu dokumanın İngiltere'den ithal edildiği görülür. Yarım yüzyılı bulmadan Osmanlı'ya pamuklu ihracatını 63 kat arttıran İngiltere, 1825 'teki toplam pamuklu ihracatın \% 2,7'sini Osmanlı'ya yaparken, bu seviye 1855 'e gelindiğinde $\% 10,7$ 'yi bulmuştur. ${ }^{54}$

52 Ayrıntılı bilgi için bakınız Donald Quataert, Osmanlı İmalat Sektörü, (Çev. T. Güney), İletişim Yayınları, İstanbul 2008.

53 Halil İnalcık, Türkiye Tekstil Tarihi Üzerine Araştırmalar, İş Bankası Kültür Yayınlar1, İstanbul 2008, s.138.

54 İnalckk, a.g.e. s. 140. 
Fiyat düşüşlerine örnek olarak seçtiğimiz kefenlik bezdeki dramatik düşüş, sadece İngiltere'nin pamuklu ihracat artışlarından değil, pamuğun bizatihi kendisinin dünya genelindeki ekim bölgelerinin artması, taşımacılıktaki maliyetlerin azalması ve teknolojinin ilerlemesiyle de ilgilidir. Söz konusu nedenlerle dünya genelinde pamuğun ortalama fiyatı (Frank/100kg) 1812'de 1.000'i geçerken, 1855 sonrasında 100 Frank'in altına düştügü dahi olmuştur. ${ }^{55}$

Gülsuyunun da değişmeyen 8 kuruşluk birim değerinin (kıyyesi) 7 kuruşa düşüşünden, malzeme fiyatlarında oranları farklı olmakla birlikte genel bir düşüş gözlemlenmektedir. Ödemeler içindeki en dikkat çekici nokta, mezarcıya mezar başına yapılan 18 kuruşluk ödemenin, aynen 1864 Mayısındaki bedel üzerinden tekrar etmesidir. Oysa 1864 Eylülünde mezar kazma işinin üç farklı biçimde; büyük, orta ve küçük olarak ayrı fiyatlandırıldığını, ancak yine o farklılaşmanın kaldırılarak bütün mezarların büyük, orta ve küçük diye ayırt etmeden hepsinin 18 kuruştan kazdırıldığını görmekteyiz. Böylece 1872 Mayısında en büyük gider kaleminin 1.098 kuruş ile yine mezar kazma ücreti olduğunu teyiden ifade etmiş oluyoruz.

\section{Sonuç}

19. Yüzyılda sivil bir hastane olarak kurulan Vakıf Gureba Hastanesi, kurulduğu tarihten itibaren Osmanlı toplumuna artan bir hızla hizmet vermiş ve günümüze kadar da aynı işlevini sürdürmeyi başarmış ender vakıf kuruluşlarından biridir. Bugün bu kuruluş, hastalara sağlık hizmeti vermesinin yanı sıra, geleceğin sağlı personellerini yetiştirmekte ve sağlık alanında araştırma ve geliştirme faaliyetleri gerçekleştirmektedir.

Vakıf Gureba Hastanesi'nde çok sayıda ve çeşitte personel istihdam edilmiştir. Ölüm olgusuna odaklanan bu makalede diğer personele de yer verilmekle birlikte ölüm vakalarına ilişkin hizmet veren personele ağırlık verilmiştir. Vakfiyede hastalara hayır dua etmesi, moral veya şifa bulmaları için akşamları Kuran okuması, ölen hastaları yıkaması ve defin işlemlerini gerçekleştirmesi için hastane camisi imamına

55 Swen Beckert, Empire of Cotton: A Global History, Alfred A. Knopf, New York 2015, s.141. 
görev verildiği kayıtlıdır. Ancak 201 yatakla hizmet vermeye başladığı 1847 yılından, 300 yatak kapasitesine çıktığı 1890-92 yıllarına kadar olan dönemde, ölen hastalara ilişkin yeni personellerin (gassal, gassal yardımcısı vb.) hastane kadrosuna alındığı ve söz konusu personellerin maaşının daha sonraki yıllarda görece olarak hayli arttı̆̆ı gözlemlenmiştir.

XIX. yüzyılın son çeyreğindeki altı aylık hastalara ilişkin verilerden hareketle, 1890 yılında aylık ölüm oranının \% 20'yi bulduğu gözlemlenmektedir. 1893 yılında hastanede yatan hastanın (273) en çok sıtma ateşi kaynaklı olduğu (\% 36), sıtma türevli diğer hastalıkları da bu sayıya kattığımızda oranın \% 50'yi bulacağı rahatlıkla ifade edilebilir. Aynı tarihteki aylık ölümün (46) ilk üç sırasını akut ve kronik bağırsak iltihabı $(\% 21,7)$, idrar $(\% 10,9)$ ve sıtmadan kaynaklanan ileri derece zayıflık $(\% 8,7)$ oluşturmaktadır. Sonraki sırayı ise 6 ölüm ile $(\%$ 6,5) üç hastalık paylaşmaktadır: Beyin-omurilik zarı iltihabı, akciğer iltihabı (zatüre) ve akciğer zarının sıvı toplanmasıyla özellenen iltihabı. Buna göre hastanede yatan sitma ve sitma türevli hastalıkların ancak \% 3'ü ölümle sonuçlanmaktadır. Kayıtlarda geçen hastalıklar, başkent İstanbul'un temizlik ve temiz su sorununun kalıcı olarak çözülmediğini veya var olan çözümün ise yetersiz olduğunu düşündürmektedir.

VGH'nin 1860-1872 y1lları arası aylık toplam gideri 43 bin ila 50 bin kuruş arasında değişirken aylık ölüm giderleri 1.160 ila 2.980 kuruş arasında değişmektedir. Yine aynı dönemde aylık ölüm 37 ila 78 arasında değişirken kişi başı ölüm (gasl ve defin) gideri 26 ila 43 kuruş arasında seyretmektedir. Ölüm giderleri arasında en yüksek kalemi kefenlik bezi oluştururken ikinci sırada mezarcıya verilen ücret yer almaktadır. Dönem sonunda ölüm masraflarına ilişkin; İngiliz pamuklu sanayisinin dokuma maliyetlerini düşürmesi sonucu masraflar arasında bez ikinci sıraya düşerken, birinci sıraya mezarcıya verilen ücretler çıkmıştır. 


\section{Kaynakça}

Arşiv

BOA: Başbakanlık Osmanlı Arşivi

EV. d. 12552, 1261.C.18. [24 Haziran 1845].

EV. d. 12552, 1261.C.18. [24 Haziran 1845].

EV. d. 12552, 1261.C.18. [24 Haziran 1845].

EV. d. 15123, 1269.Z.9. [14 Ağustos 1853].

EV. d. 15428, 1270.Za.19. [6 Ağustos 1854].

EV. d. 15552, 1271.S.21. [13 Kasim 1854].

EV. d. 16049, 1272.Z.11. [13 Ağustos 1856].

EV. d. 19208, 1280 Teşrînievvel. [Eylül 1864].

EV. d. 24395, 1296.M.19. [13 Ocak 1879].

EV. d. 28077, 1311.Ra.3, [14 Eylül 1893].

İ. DH. $138 / 7116$.

İ. MSM. 25/665.

İ. MSM. 25/666.

Y. PRK. EV. 1.74, 1307.B.22. [14.03.1890].

VGMA: Vakıflar Genel Müdürlüğ̈̈ Arşivi

Bezmiâlem Valide Sultan Vakıf Gureba Hastanesi -BVS VGH- Vakfiyesi, (Sultan Mahmud-ı Sâni, Bezmiâlem, Pertevniyal Valide Sultan Vakfyeleri, Kasa no. 11, Defter no. 634, s.113-120) BVS'nin 15 Vakfiyesi 1256-1269 [1840-1853] arasinda 83. Sayfa 13. Sira ila 126. Sayfa 27. Sira arasi.

\section{Süreli Yayınlar}

Servet-i Fünûn: Kadri, “Artezyen Kuyuları”, İstanbul, 19 Ağustos 1309 [31 Ağustos 1893], C.5, S.129 ve "Mevâdd-1 T1bbiye ve Sihhiye", 19 Ağustos 1309 [31 Ağustos 1893], C.5, S.129; "Mevâdd-1 Tıbbiye ve Sihhiye”, 9 Eylül 1309 [21 Eylül 1893], C.6, S.132; "Dersaadet Anadolu Ciheti Suları", 16 Eylül 1309 [28 Eylül 1893], C.6, S.133; “Mikroplar”, 12 Teşrinievvel 1309 [24 Ekim 1893], C.6, S.138; “İskambil Kağıdları ve Mikroplar”, 19 Teşrinievvel 1309 [31 Ekim 1893], C.6, S.139. Takvim-i Vekayi: No: 294, 23 Zilkade 1261/ 23 Kasim 1845. 


\section{Kitap, Makale, Madde ve Tez.}

Akgündüz, Ahmed. İslam Hukukunda Kölelik-Cariyelik Müessesesi ve Osmanlı'da Harem. İstanbul: Osmanlı Araştırmaları Merkezi Yayınları, 2006.

Artvinli, Fatih. Delilik Siyaset ve Toplum: Toptaşı Bimarhanesi (18731927). İstanbul: Boğaziçi Üniversitesi Yayınevi, 2013.

Ayar, Mesut. Osmanlı Devletinde Kolera İstanbul Örneği (1892-1895). İstanbul: Kitabevi, 2007.

Beckert, Swen. Empire of Cotton: A Global History. New York: Vintage Books, 2015.

Devellioğlu, Ferit. Osmanlıca-Türkçe Ansiklopedik Lûgat. Ankara: Aydın Kitabevi Yayınları, 1996.

Göçer, Kenan. "Bezmiâlem Valide Sultan ve Gureba Hastanesi Vakfiyesi." Çankırı Karatekin Üniversitesi İktisadi ve İdari Bilimler Fakültesi Dergisi, 4 (1), (2014): 123-150.

Gürkan, Kazım İsmail. Bezm-i Âlem Vâlide Sultan Vaklf Gureba Hastanesi Tarihçesi. İstanbul: Özışık Matbaası, 1967.

Henderson, John. The Renaissance Hospital: Healing the Body and Healing the Soul. New Haven, 2006.

İnalcık, Halil. Türkiye Tekstil Tarihi Üzerine Araştırmalar. İstanbul: İş Bankası Kültür Yayınları, 2008.

Lindemann, Mary. Erken Modern Avrupa'da Tıp ve Toplum, Çev.: M. Doğan. İstanbul: Boğaziçi Üniversitesi Yayınevi, 2013.

Nikiforuk, Andrew. Mahşerin Dördüncü Atlısı: Salgın ve Bulaşıcı Hastalıklar Tarihi, Çev.: S. Erkanlı. İstanbul: İletişim Yayınları, 2010.

Okutan, M. Yahya, vd. (Haz.) Yâdigâr-ı İbn-i Şerîf. İstanbul, 2004.

Öztuna, Yılmaz. Osmanlı Devleti Tarihi Medeniyet Tarihi, C. 2. İstanbul: Ötüken Yayınları, 2006.

Quataert, Donald. Osmanlı İmalat Sektörü, Çev.: T. Güney. İstanbul: İletişim Yayınları, 2008.

Paspatis, Aleksandros. Balıklı Rum Hastanesi Kayıtlarına Göre İstanbul'un Ortodoks Esnafi 1833-1860, Çev. M. Yerasimos. İstanbul: Kitap Yayınevi, 2014. 
Risse, Guenter. Hospital Life in Enlightenment Scotland: Care and Teaching at the Royal Infirmary of Edinburgh. Cambridge, 1986.

Şentürk, M. Hüdai. "Bezmiâlem Valide Sultan”, İslam Ansiklopedisi, C. 6. İstanbul: Türkiye Diyanet Vakfı Vakıf Yayınları, 1992.

Tetik, Fatih. “Osmanlı Devleti'nin Tanzimat Dönemi Kamu Să̆lığı Politikası." Yayınlanmamış Yüksek Lisans Tezi, Marmara Üniversitesi, Türkiyat Araştırmaları Enstitüsü, 2007.

Unat, Ekrem Kadri, vd. (Haz.). Osmanlıca Tip Terimleri Sözlüğü. Ankara: Türk Tarih Kurumu Yayınları, 2004.

Yıldırım, Nuran. Gureba Hastanesi’nden Bezmiâlem Vakıf Üniversitesi'ne. İstanbul: Bezmiâlem Vakıf Üniversitesi Yayını, 2013.

Yıldırım, Nuran. İstanbul'un Sağlık Tarihi, İstanbul 2010 Avrupa Kültür Başkenti Ajansı İstanbul Üniversitesi Projesi No 55-10, İstanbul 2010.

Zîver Paşa. Âsâr-1 Zîver: Dîvan ve Münşeât, Nşr.: Y. Bahaeddin. Bursa: Matbaa-i Vilayet, 1313 [1896]. 